Meta

Journal des tradlucteurs

Translators' Journal

\title{
Petit vocabulaire contextuel des matières plastiques
}

\section{Robert Serré}

Volume 24, numéro 2, juin 1979

URI : https://id.erudit.org/iderudit/004099ar

DOI : https://doi.org/10.7202/004099ar

Aller au sommaire du numéro

Éditeur(s)

Les Presses de l'Université de Montréal

ISSN

0026-0452 (imprimé)

1492-1421 (numérique)

Découvrir la revue

Citer cet article

Serré, R. (1979). Petit vocabulaire contextuel des matières plastiques. Meta, 24(2), 264-273. https://doi.org/10.7202/004099ar d'utilisation que vous pouvez consulter en ligne.

https://apropos.erudit.org/fr/usagers/politique-dutilisation/ 


\section{Les banques de terminologie bilingues et multilingues: état de la question*}

On trouvera dans le présent exposé quatre parties : d'abord, en introduction, des considérations générales, puis une définition de certains termes clés, suivie d'un bilan des banques de terminologie. Enfin, nous étudierons les problèmes particuliers que posent le bilinguisme et le multilinguisme aux banques de terminologie.

Le cas des banques de terminologie monolingues sera exclu de nos considérations, d'abord parce que même si en théorie rien ne s'oppose à leur création, il ne s'en trouve pas dont nous connaissions l'existence; ensuite parce que les problèmes qu'elles posent ne diffèrent pas, sauf par leur nombre, de ceux que l'on rencontre dans les banques de terminologie bilingues et multilingues.

Les banques de terminologie sont un phénomène extrêmement récent, né d'une part du besoin grandissant du monde moderne - dans lequel se multiplient de plus en plus rapidement les développements scientifiques et techniques d'homologuer et de classer un nombre de plus en plus important de termes et d'autre part des possibilités qu'offrent à la fois l'informatique et les nouvelles générations d'ordinateurs.

La création de termes n'a rien de nouveau : les philosophes grecs et les commerçants crétois avaient développé leur terminologie propre. Ce qui est nouveau, ce qui caractérise notre époque, c'est la masse de plus en plus importante des termes. Le rapport entre la masse terminologique et la masse lexicale de la langue commune s'inverse progressivement et, à moins de changements radicaux, il semble bien que le processus soit irréversible. La terminologie - de même que son complément, la néologie - est le produit direct de la société moderne. S'il naît des banques de terminologie à l'heure actuelle - et il s'en crée une ou deux par année dans le monde depuis cinq ou six ans - c'est pour répondre à un besoin d'ordre sociolinguistique.

Par ailleurs, l'outil qui permet de répondre à ce besoin est double : c'est d'une part l'informatique, ou la science du traitement des données, dont les développements permettent de mettre au point des logiciels de plus en plus raffinés et établis spécifiquement en vue du traitement des données linguistiques et d'autre

* Exposé présenté au CIRB de l’Université Laval le 8 février 1978. 


\section{BREAKER PLATE}

See also : screen pack

The plastic is delivered through a breaker plate and screens to the die (Patton 1976 197)

- un filtre est souvent interposé entre le corps de boudineuse et la tête; il est formé par une plaque d'acier percée de trous cylindriques obligeant la matière à se diviser en nombreux filets (Gossot 1968 111)

— le filtre, appelé aussi plaque de freinage (Gossot 1968 111)

\section{BUBBLE}

See also : tubular film

To blow the tube of plastic into a bubble (Patton 1976 203)

— une gaine à parois minces (EIST 81972 956)

- une gaine mince qui, par fendage, fournit une feuille (Gossot 1968 117)

\section{CAST FILM}

Also : flat film, cast flat film

See also : tubular film, slot die

Like sheet, extruded through a linear slot die and cooled by contact with a polished metal roll (Patton 1976 203)

- le matériau sort sous forme d'une bande qui doit être refroidie rapidement (EIST 51971546 )

- l'extrusion par filière plate pour la fabrication de films et de feuilles (EIST $5197158)$

— feuille plane (Aubineau 1974205 )

\section{COMPOSITE}

Also : composite plastics

See also : laminate, reinforced plastics

Reinforced materials are termed composites (Patton 1976 21)

— les complexes ; ceux-ci associent au moins deux matériaux (EIST 51971 60)

\section{CROSSHEAD DIE}

(used in) wire and cable coating... the wire travelling at right angles to the flow of the polymer (Patton 1976 205)

- la tête de boudineuse... tête d'équerre ; tête d'angle lorsque l'angle formé... n'est pas de $90^{\circ}$ (Gossot 1968 110-111)

\section{CULL}

See also : sprue

Material remaining in a transfer chamber after mold has been filled (Frados 1976 7) 
- le piston de transfert comporte à sa base une cavité dite «tenon » qui retient la carotte et le culot de moulage, assurant ainsi le nettoyage de la chambre de transfert à l'ouverture (Gossot 1968 137)

\section{DEEP-DRAWN PART}

Also : deep-formed part

Each inch of cavity depth beyond the first inch... deep draws (Patton 1976 172,210)

- le moulage de pièces profondes ayant de hautes parois ; des emboutis profonds ; des moulages profonds (Gossot 1968 137,266,275)

\section{DEFLASHING}

Also : definning

Covers the range of finishing techniques used to remove the flash (Harper 1975 4)

- l'ébarbage de la pièce finie (Gossot 1968 135)

\section{DEGATING}

- le décarottage peut être effectué simplement par cassure (Domininghaus 1973 115)

DIE

See : CROSSHEAD DIE, SLOT DIE

\section{DRAFT}

See also : undercut

The degree of taper of a side wall or the angle of clearance designed to facilitate removal of parts from a mold (Frados 1976 9)

- la dépouille est la possibilité géométrique d'extraire l'objet de l'empreinte... l'angle de dépouille (Gossot 1968 131)

\section{EXTRUDER}

Also : extrusion press, extrusion machine

See also : barrel, screw

- la machine, appelée boudineuse ou extrudeuse (Aubineau 1974 204)

\section{FILAMENT WINDING}

A process in which continuous reinforcements previously impregnated with a matrix material or impregnated during the winding are placed over a rotating and removable form or mandrel (Harper 1975 6)

- le bobinage filamentaire (Universalis 131972 155)

- composites préparés par enroulement filamentaire hélicoïdal croisé (Geldreich 1975 429) 


\section{FILLER}

Also : filling material

A relatively inert material added to a plastic to modify its strength, permanence, working properties, or other qualities, or to lower costs (ASTM 1976 349)

- des charges inertes pour diminuer le prix (Universalis 131972 155)

- charges granulaires; charges fibreuses ; charges granulaires minérales ; charges granulaires organiques (EIST 81972 954)

\section{FLASH}

Also : fin

See also : parting line, deflashing

Extra plastic attached to a moulding along the parting line (Frados 1976 15)

- une bavure verticale très mince (Gossot 1968 132)

\section{FOAMED PLASTICS}

Also : bubble pl., cellular pl., expanded pl., foam pl., plastic foams

Plastics containing numerous small cavities (cells), interconnecting or not, distributed throughout the mass (ASTM 1976 347)

- des plastiques expansés ou allégés (Universalis 131972 155)

- mousses plastiques (Sourles 1968 65)

— produits cellulaires plastiques ; mousses (Gossot 1968 198-199)

— produits rigides (souples) alvéolaires (Anon. 1970 37)

\section{FOAMING AGENT}

Also : blowing agent

- un agent porogène qui libère un gaz sous l'influence de la chaleur (Universalis 131972155 )

- un porophore ou agent gonflant (Gossot 1968 201)

- agent gonflant, agent d'expansion (Domininghaus 1974 113)

\section{GATE}

The short, usually restricted section of the runner at the entrance to the cavity of an injection or transfer mold (Frados 1976 17)

- passage de la matière au niveau de la buse, des canaux, des seuils d'injection et du moule (Chevalier 1974 83)

- l'orifice par lequel le canal d'alimentation débouche dans la cavité (Gossot 1968 147)

\section{GRANULES}

Also : chips, pellets

See also : preform, molding powder 
- granulés billes, granulés cylindriques, granulés cubiques, granulés copeaux (Gossot 1968 112)

- la trémie de chargement de chips (granules de polymère) (EIST 51971 546)

HEAD

See also : crosshead die

— la tête de boudineuse sert de support à la filière (Gossot 1968 110)

\section{INJECTION MOLDING}

The process of forming a material by forcing it, under pressure, from a heated cylinder through a sprue (runner, gate) into the cavity of a closed mold (ASTM 1976 350)

- le moulage par injection (Universalis 131972 155) (Aubineau 1974 206)

\section{LAMINATE}

Also : laminated plastic

See also : composite, reinforced plastics

A product made by bonding together two or more layers of material or materials (ASTM 1976 351)

High molding pressures (1200 to 2500 psi) are used (DuBois 1974 387)

- moulage de stratifiés « haute pression» (EIST 81972 954)

- les stratifiés sont composés d'un empilage de strates constituées par des feuilles enduites de résine et agglomérées sous presse pour former un matériau compact (Gossot 1968 97)

\section{MANDREL}

Also : core

See also : breaker plate, spider

The solid, cylindrical part of the die that forms tubing or pipe (Frados 1976 25)

- le filtre sert de support au poinçon dont la présence est nécessaire pour la formation des tubes ou des profilés creux (Gossot 1968 111)

\section{MOLDING POWDER}

Also : molding material, molding compound

See also : granules, preform

Plastic material in varying stages of granulation, often comprising resin, filler, pigments, plasticizers and other ingredients, ready for use in the molding operation (Frados 1976 27)

— poudres à mouler (par ex. la bakélite) (EIST 81972 956)

- la matière à mouler dosée (Chevalier 1974 77)

- les poudres à mouler (Gossot 1968 91) 
NOZZLE

See also : sprue

The fluid plastic is forced into the mold through a nozzle connecting the cylinder and the mold (Patton 1976 176)

— une buse dont l'extrémité plate ou arrondie assure la jonction avec le moule au moment de l'injection (Gossot 1968 141)

- des buses à obturation (Domininghaus 1973 114)

\section{PARISON}

The shaped plastic mass, generally in the form of a tube, used in blow molding (ASTM 1976 352)

- un tube apte à être dilaté par insufflation d'air (Gossot 1968 265)

- gonflage du tuyau dès la sortie de la filière (Universalis 131972 158)

\section{PARTING LINE}

Also : cut-off, flash line, flash groove, pinch-off, split line

The line where the two halves of a mold come together (Frados 1976 7)

- le plan de joint (Gossot 1968 147)

\section{PIREFORM}

Also : biscuit, cake, pellet, pill, slug

See also : granules, molding powder

A compressed tablet or biscuit of plastic composition used for efficiency in handling and accuracy in weighing materials (Frados 1976 30)

- soit une ébauche de l'objet (préforme), soit des disques ou des parallélépipèdes compacts (pastilles) (Gossot 1968 120-121)

\section{REINFORCED PLASTICS}

Also : filled plastics

See also : composite, laminate

A plastic with strength properties greatly superior to those of the base resin, resulting from the presence of reinforcements in the composition (Harper 1975 11)

Low molding pressures are employed (0 to 1000 psi) (DuBois 1974 387)

- les plastiques armés, encore appelés plastiques renforcés (Aubineau 1974 208)

\section{RELEASE AGENT}

Also : mold release, parting agent

A lubricant used to coat a mold cavity to prevent the molded piece from sticking to it, and thus to facilitate its removal from the mold (Frados 1976 27) 
- l'agent de démoulage (cire, graisse, etc.) (EIST 81972 954)

- plaque de verre enduite de démouleur (Sourles 1968 21)

— des démoulants (Chevalier 1974 77)

\section{ROTATIONAL MOLDING}

Also : rotational casting, rotary moulding

A method used to make hollow articles from thermoplastic materials ; material is charged into a hollow mold capable of being rotated in one or two planes; the hot mold fuses the material into a gel after the rotation has caused it to cover all surfaces; the mold is then chilled and the product stripped out (Frados 1976 32)

- le moulage par rotation (Universalis 131972 155) (Gossot 1968 260) (EIST 5 1971 58)

- rotomoulage : technique qui consiste à couler un matériau dans un moule en rotation de façon à le répartir sur les parois (CILF. la Clé des mots, juillet-août 1974, fiche 1755)

\section{RUNNER}

The channel that connects the sprue with the gate to the cavity (Frados 1976 32)

- lors du passage de la matière au niveau de la buse, des canaux, des seuils d'injection et du moule (Chevalier 1974 83)

- le canal d'alimentation débouche dans la cavité du moule (Gossot 1968 147)

\section{SCREEN PACK}

Also : screens

See also : breaker plate

The plastic is delivered through a breaker plate and screens to the die... the screen pack consists of several layers of stainless wire screen which strain out foreign material and unmelted granular plastic (Patton 1976 197)

- un tamis à mailles fines qui arrête les petites impuretés ou les grains durs de matière mal plastifiée (Gossot 1968 111)

\section{SCREW}

- les extrudeuses modernes sont à vis sans fin (Universalis 131972 155)

- les vis dix diamètres, les vis douze diamètres... à filets simples (doubles), à pas variable (constant), à noyau conique (droit) (Gossot 1968 109-110)

\section{SIZING PLATES}

Also : sizing units, sizer

The pipe takes its size by passing through a series of metal sizing plates (Patton 1976 201)

- le conformateur monté directement après la filière de la boudineuse (Domininghaus 1974 91) 


\section{SLOT DIE}

See also : cast film

Slot extrusion : a method of extruding film sheet in which the molten thermoplastic compound is forced through a straight slot (Frados 1976 34)

- l'extrusion par filière plate pour la fabrication de films et de feuilles (EIST 5 1971 58)

— des filières à fente (EIST 51971 546)

\section{SPIDER}

See also : mandrel

The membranes supporting a mandrel within the head/die assembly (Frados 1976 35)

- le poinçon est maintenu par des ailettes (Domininghaus 1974 96)

\section{SPRUE}

Also : spur

See also : cull

The passage between the nozzle and the runners (Patton 1976 176)

The slug formed at this passage (Frados 1976 35)

- la carotte d'injection; les carottes et les pièces manquées sont réutilisées

(Gossot 1968 147-148)

\section{TAKEOFF DRIVES}

Also : takeaway

See also : sizing plates

The extrudate is pulled from the die through the cooling and sizing unit by takeoff drives (Patton 1976 200)

- un système d'entraînement du profilé comportant un tapis de tirage dont la vitesse de déroulement est réglée sur celle de la sortie du profilé (Gossot 1968 111)

— afin de faciliter le tirage du profilé (Domininghaus 1974 91)

\section{TORPEDO}

\section{Also : spreader}

A streamlined metal block placed in the path of flow of the plastics material in the heating cylinder... to spread it into thin layers, thus forcing it into intimate contact with the heating areas (Frados 1976 35)

- une pièce métallique dite «torpille» dont le rôle est d'améliorer les échanges thermiques avec la matière (Gossot 1968 141)

\section{TRANSFER MOLDING}

A method of molding thermosetting materials, in which the plastic is first softened by heat and pressure in a transfer chamber, then forced by high 
pressure through suitable sprues, runners, and gates into closed mold for final curing (Frados 1976 37)

— moulage par transfert (EIST 81972 954) (Aubineau 1974 205)

\section{TUBULAR FILM}

Also : blown film

See also : cast film, bubble

The plastic is extruded vertically from an annular die... air is admitted through the center of the die mandrel to blow the tube of plastic into a bubble to thin the tube wall to final thickness, after which the tube is slit to make a flat film (Patton 1976 203)

- les gaines et films sont obtenus par simple gonflage du tuyau dès la sortie de la filière (Universalis 131972 158)

— une gaine à parois minces (qui donnera) un film (EIST 81972 956)

— un tube est extrudé verticalement... poinçon permettant l'arrivée d'air... pour que la dilatation amincisse la paroi du tube jusqu'à l'épaisseur finale souhaitée (Gossot 1968 117)

- on utilise une filière annulaire comme pour les gaines soufflées normales ; à la sortie de la machine, la feuille tubulaire... est soufflée par de l'air comprimé (Domininghaus 1973 121)

\section{UNDERCUT}

See also : angle press, draft

Protuberation or indentation that impedes withdrawal from a two-piece, rigid mold (Frados 1976 37)

- le démoulage des objets qui présentent une «contre-dépouille », c'est-à-dire dont la forme ne permettrait pas sans cela l'extraction du moule (Gossot 1968 132)

ROBERT Serré

\section{SOURCES}

ANON. 1970

Anon., «La transformation des matières plastiques 》, Hauts polymères, no 28,1970 , p. 21-39.

ASTM 1976

Annual Book of ASTM Standards, Philadelphia, American Society for Testing and Materials, 1976, Part 35 : Plastics, p. 346-359: Definitions.

AUBINEAU 1974

Claude Aubineau, Roland Audebert, les Polymères organiques, Paris, PUF, 1974, 232 p.

CHEVALIER 1974

CILF

M. Chevalier, «Les phénoplastes, des thermodurcissables moulables par injection », Plastiques modernes et élastomères, vol. 26 , no 2,1974 , p. $75-85$.

Conseil international de la langue française, la Clé des mots, Paris (mensuel). 
DOMININGHAUS 1973 H. Domininghaus, G. Trausen, B. Rapp, «Thermoplastiques allégés; problèmes d'injection et d'extrusion 》, Plastiques modernes et élastomères, vol. $25, \mathrm{n}^{0} 7,1973$, p. 112-126.

DOMININGHAUS 1974 H. Domininghaus, «Profilés pleins et creux en thermoplastiques cellulaires 》, Plastiques modernes et élastomères, vol. 26 , no 8 , 1974, p. 110-114 et vol. 26, no 9, 1974, p. 91-96.

DuBOIS 1974

J. Harry DuBois, Frederick W. John, Plastics, New York, Van Nostrand Reinhold Co., 5th ed,, 1974, p. xii-543.

EIST

FRADOS 1976

Encyclopédie internationale des sciences et des techniques; les Presses de la Cité.

Joel Frados, ed., Plastics Engineering Handbook of the Society of the Plastics Industry, Inc., New York, Van Nostrand Reinhold Company, 4th ed., 1976, p. xvi-909.

GELDREICH 1975

GOSSOT 1968

L. Geldreich, P. Huber, «Comportement mécanique de matériaux composites préparés par enroulement filamentaire $»$, Revue générale des caoutchoucs et plastiques, vol. 52, no 6,1975 , p. 429-432.

J. Gossot, les Matières plastiques, fabrication - technologie, Paris, Dunod, 3e éd., 1968, p. viii-316.

HARPER 1975

Charles A. Harper, ed.-in-chief, Handbook of Plastics and Elastomers, New York, McGraw-Hill Book Company, 1975.

PATTON 1976

William J. Patton, Plastics Technology; theory, design and manufacture, Reston, Virginia, Reston Publishing Co., Inc., 1976, p. xiv-273.

SOURLES 1968

Pierre-René Sourles, les Matériaux nouveaux à la portée de l'amateur; les plastiques, Saint-Brieuc, Éditions Delta, 1967, 110 p.

UNIVERSALIS

Encyclopadia Universalis, Paris, Encyclopædia Universalis France. 